\title{
AN EXTENSIVE PERMANENT SNOWFIELD AND THE POSSIBLE OCCURRENCE OF PERMAFROST IN TILL IN THE RIDNITŠOHKKA AREA, FINNISH LAPLAND
}

\author{
HEIKKI HIRVAS, PETRI LINTINEN and PEKKA KOSLOFF
}

HIRVAS, HEIKKI, LINTINEN, PETRI and KOSLOFF, PEKKA 2000. An extensive permanent snowfield and the possible occurrence of permafrost in till in the Ridnitšohkka area, Finnish Lapland. Bulletin of the Geological Society of Finland 72, Parts 1-2, 47-56.

An area of permanent snow and frozen ground was studied at the end of summer seasons during the years 1990-1993 near the summit of Ridnitšohkka fell, which at $1317 \mathrm{~m}$ a.s.l. is the second highest peak in Finland. The eastern flank of Ridnitšohkka has the most extensive area of permanent snow $\left(3 \mathrm{~km}^{2}\right)$ in Finland, while the summit region represents the highest single area of basal till devoid of vegetation cover and displaying patterned ground features.

The ground penetrating radar results show that the form of the snowfield does not conform to the topography of the underlying bedrock and reveal the presence of several continuous reflectors dipping down-slope. Observations based on drilling and a single test pit indicate that the snowfield is $6.2 \mathrm{~m}$ thick and that it contains discontinuous lenses or layers of ice from 2 to $30 \mathrm{~mm}$ in thickness. Plant material from the depth of $4.05 \mathrm{~m}$ in the drilling core yielded a radiocarbon age of 35 years, while variations in the size of lichens growing at the edge of the snowfield indicated that the snowfield was of considerably greater extent some 100 to 150 years ago. The results suggest that the snowfield has been stable for a relatively long period but the "residence time" of snow in the snowfield is rather short, presumably less than 100 years and possibly only a few decades.

Percussion drilling on the Ridnitšohkka summit plateau, situating $1290 \mathrm{~m}$ a.s.l., revealed that the till was frozen at the depth of $1.9 \mathrm{~m}$ at the end of July 1993. Discovery of frozen till shows that frozen ground can locally survive from one season to the next, while the extent of the permanent snowfield and vegetationfree patterned ground suggest that the conditions favourable for permafrost might have existed over wider areas.

Key words: periglacial features, snow, firn, permafrost, till, drilling, Ridnitšohkka, Lapland, Finland

Heikki Hirvas and Petri Lintinen: Geological Survey of Finland, P.O. Box 96, FIN-02151 Espoo, Finland.

E-mail: heikki.hirvas@gsf.fi; petri.lintinen@gsf.fi

Pekka Kosloff: Finnish Institute of Marine Research, P.O. Box 33, FIN-00931 Helsinki, Finland.

E-mail.pekka.kosloff@fimr.fi 


\section{INTRODUCTION}

Perennial snowfields occur in some favourable sites in Finnish Lapland. The largest number of perennial snowfields is situated in the east or north-east facing gullies and nivation hollows in fell slopes at the north-western part of the Enontekiö district. In this area many of the fell summits exceed the elevation of $1000 \mathrm{~m}$ above sea level. According to Østrem (1964), the theoretical glaciation limit, i.e. the minimum altitude required for glaciers, in the north-western part of the Enontekiö district is $1450 \mathrm{~m}$ a.s.l., which is relatively close to the altitude of the highest fell summit in Finland.

Northern Lapland is classified climatologically as belonging to the zone containing sporadic occurrences of permafrost (Péwé 1979), with a mean annual temperature of between $0^{\circ} \mathrm{C}$ and $-3^{\circ} \mathrm{C}$ (Helminen 1987). The presence of palsa bogs is the most diagnostic indication that permafrost exists at least locally in northern Lapland and indeed the presence of palsa features is commonly taken to delineate the southernmost occurrence of permafrost conditions (Fig. 1). Palsa landforms can be traced across northernmost Finland from just north of Lake Inari through Hietatievat and further westwards at a latitude of $68^{\circ} 25^{\prime}$ to the Swedish border (King \& Seppälä 1987).

Electrical conductivity measurements carried out on several summits above the tree line, where winter snow cover is relatively thin, have been postulated to indicate the presence of permafrost horizons which may be as much as $10-50 \mathrm{~m}$ thick (King \& Seppälä 1987). The thickness of the active permafrost layer in Finnish Lapland has also been estimated by measuring temperature gradients (Putkonen 1990) and the temperature data from Lapland have been compared with temperature measurements from the active permafrost layer in the Disko area of Greenland. The interpretations by Putkonen (1990) were somewhat at variance with those of King and Seppälä (1987) pointing only to the existence of seasonal frost at some sites. However, permafrost was explicitly observed on the fell summit of Ylläs in a drilled well being frozen at $40 \mathrm{~m}$ depth below the bed- rock surface (King \& Seppälä 1987).

During the course of till stratigraphic investigations carried out by the Geological Survey of Finland in the summer of 1974, six study pits were excavated along a road trending north-eastwards from Kilpisjärvi (Hirvas 1990). The study pits were excavated between 10th and 13th July, at elevations of between $490 \mathrm{~m}$ and $545 \mathrm{~m}$ and even though the deepest pit was excavated down to $7.5 \mathrm{~m}$, no signs of permafrost or frozen till were found anywhere. Subsequent studies have likewise failed to find direct confirmation of the presence of frozen minerogenic ground in the proximity to palsa bogs in late summer. However, during the road construction work at Peera, near Kilpisjärvi, peat and glacilacustrine silt underlying the road structure are expected to be permanently frozen due to the artificially induced heat conduction through the snow-free road surface (Saarelainen 1990).

The purpose of our investigations has been to study the permanent snow and describe periglacial phenomena on the second highest fell in Finland. This area is characterized by the harshest climatic conditions in the country and contains both the largest permanent snowfield, $3 \mathrm{~km}^{2}$ in size (Fig. 2), and an extensive area of patterned ground devoid of vegetation. A programme involving radar survey, drilling and excavation of study pits was undertaken in order to study the history and internal structures of the snowfield. Drillings were also conducted to find direct evidence for frozen minerogenic ground at the end of the summer season, which would at least in principle mean that permafrost might be found on the highest and most exposed summits in northernmost Lapland.

\section{STUDY AREA}

The Ridnitšohkka fell is located in the north-western extremity of the Enontekiö district, adjacent to the Norwegian border (Fig. 1). The bedrock in the region consists primarily of allochthonous sheets of early Palaeozoic rocks that were thrust south-eastwards over the Fennoscandian Shield 


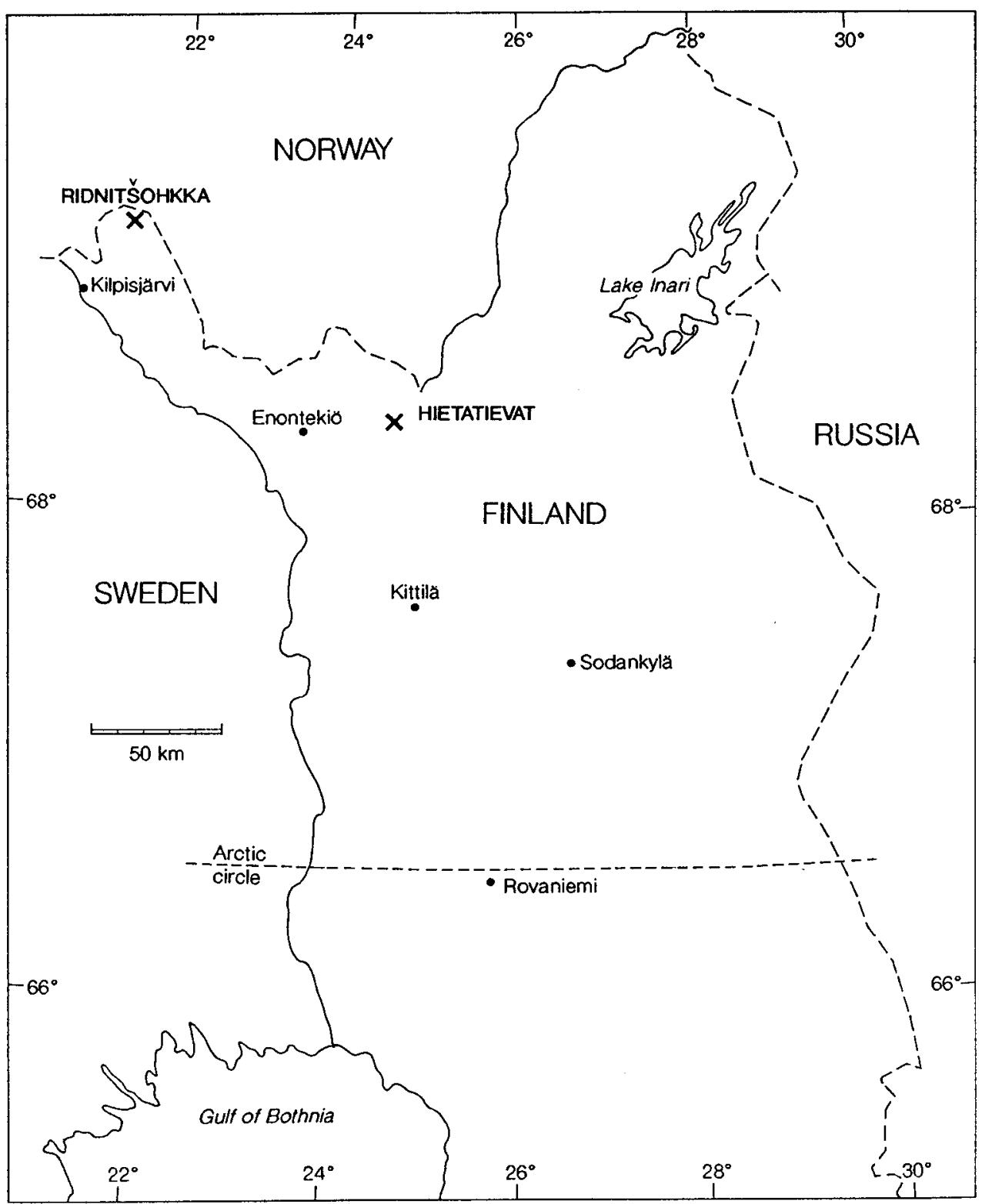

Fig. 1. The location of the Ridnitšohkka fell in Northern Finland, Lapland. The southern boundary of palsa bogs and the potential southern boundary of sporadic permafrost runs from north of Lake Inari through Hietatievat and further westwards at a latitude of 68²5' to the Swedish border (King \& Seppälä 1987).

and a thin Cambrian sedimentary sequence during the Caledonian orogeny, some 400-500 million years ago. The allochthonous units dip gently towards the north-west and extend for only about 10-20 km into Finland from the Norwegian border (cf. Simonen 1980, Lehtovaara 1995).
The Kilpisjärvi-Ridnitšohkka area contains all of the Finnish peaks that have elevations greater than $1000 \mathrm{~m}$ above sea level. Relatively broad, yet steep-sided valleys separate the higher peaks from one another, resulting in the greatest topographical relief to be found in Finland, with 200-500 m 


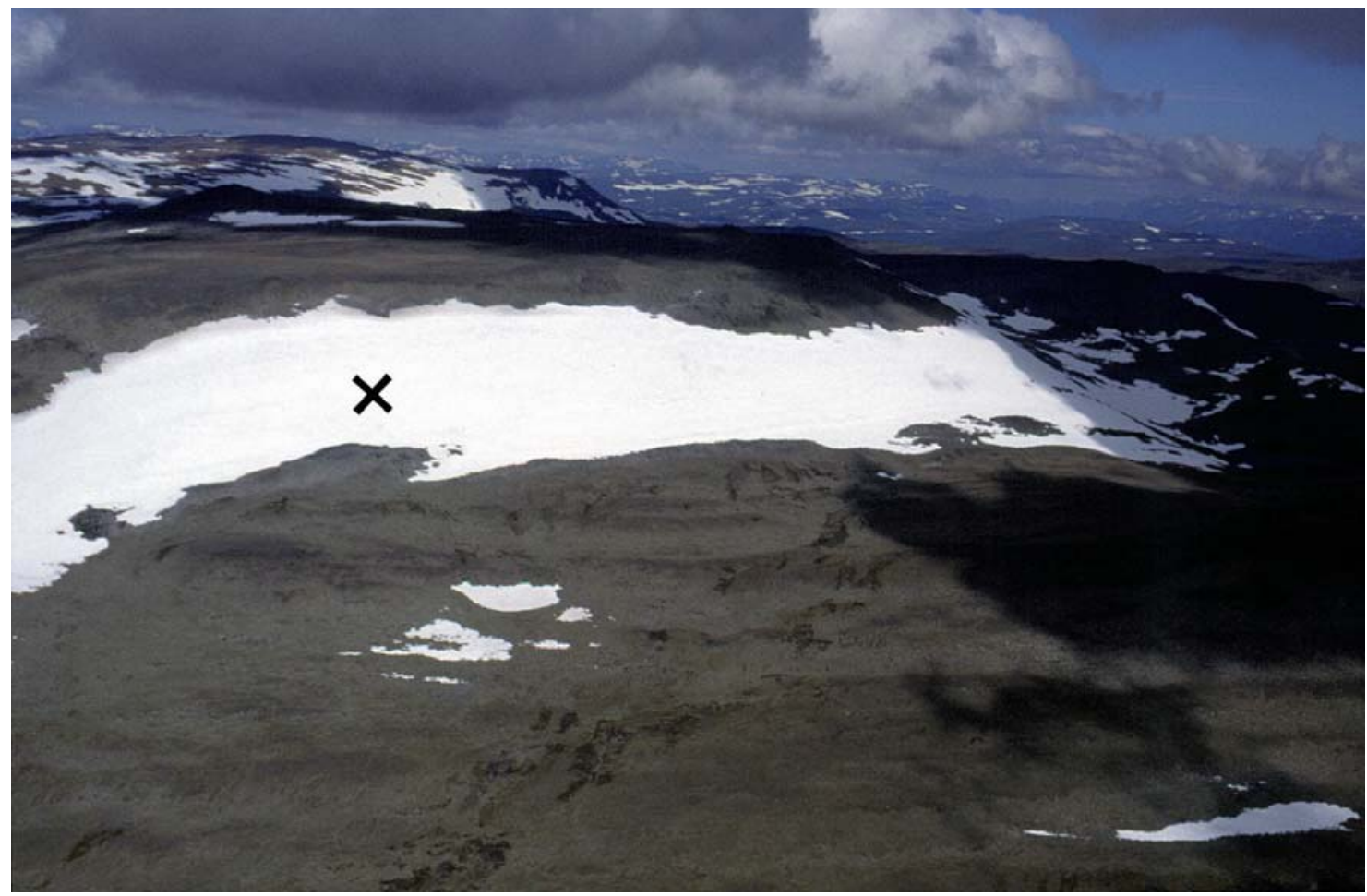

Fig. 2. An oblique aerial photograph from the eastern slope of Ridnitšohkka. The snowfield is about $5 \mathrm{~km}$ long and $600 \mathrm{~m}$ broad. The drilling location is marked with $X$.

differences in elevation between summits and valley floors being typical.

Various morphological features in the HaltiRidnitšohkka area are indicative for past mountain glaciation, untypical for the other regions of Finnish Lapland. For example, the steep-sided Kovdajohka valley has evidently been occupied by a $5 \mathrm{~km}$ long valley glacier. The terminal positions of this glacier have been recorded by a distinct set of end-moraines (Hirvas 1968). Also the present well-developed cirques, e.g. in the north-east face of Kovddoskaisi and south-east slope of Ridnitšohkka, with associated end-moraines, are firm evidences for former mountain glaciers. According to Kujansuu $(1967,1992)$, the mountain glaciers were active after the Scandinavian ice sheet had retreated to the south some 9000-10 000 years ago.

There are no climatic data available for the summit of Ridnitšohkka itself, but inferred average temperatures can be estimated from the data recorded at Kilpisjärvi (478 m above sea level). The mean annual temperature for Kilpisjärvi is $-2.6^{\circ} \mathrm{C}$, while for January it is $-14.6^{\circ} \mathrm{C}$ and for July $+10.6^{\circ} \mathrm{C}$ (Finnish Meteorological Institute 1991). On the basis of a decrease of $0.5^{\circ} \mathrm{C}$ for every $100 \mathrm{~m}$ increase in altitude (Laaksonen 1976), an annual mean temperature of $-6.8^{\circ} \mathrm{C}$ is obtained for Ridnitšohkka, with January and July mean values of $-18.8^{\circ} \mathrm{C}$ and $+6.4^{\circ} \mathrm{C}$, respectively.

The summit and upper slopes of Ridnitšohkka are in many places devoid of vegetation and show extensive active patterned ground, exhibiting welldeveloped polygonal features and evidence of solifluction. Evidence for contemporary patterned ground formation includes the abundance of boulders and rocks lacking any traces of lichen growth and conversely, the presence of lichen on the underside of inverted boulders.

A series of distinctive solifluction terraces or lobes are developed in till on the eastern flank of Ridnitšohkka. Further down-slope, at an elevation 


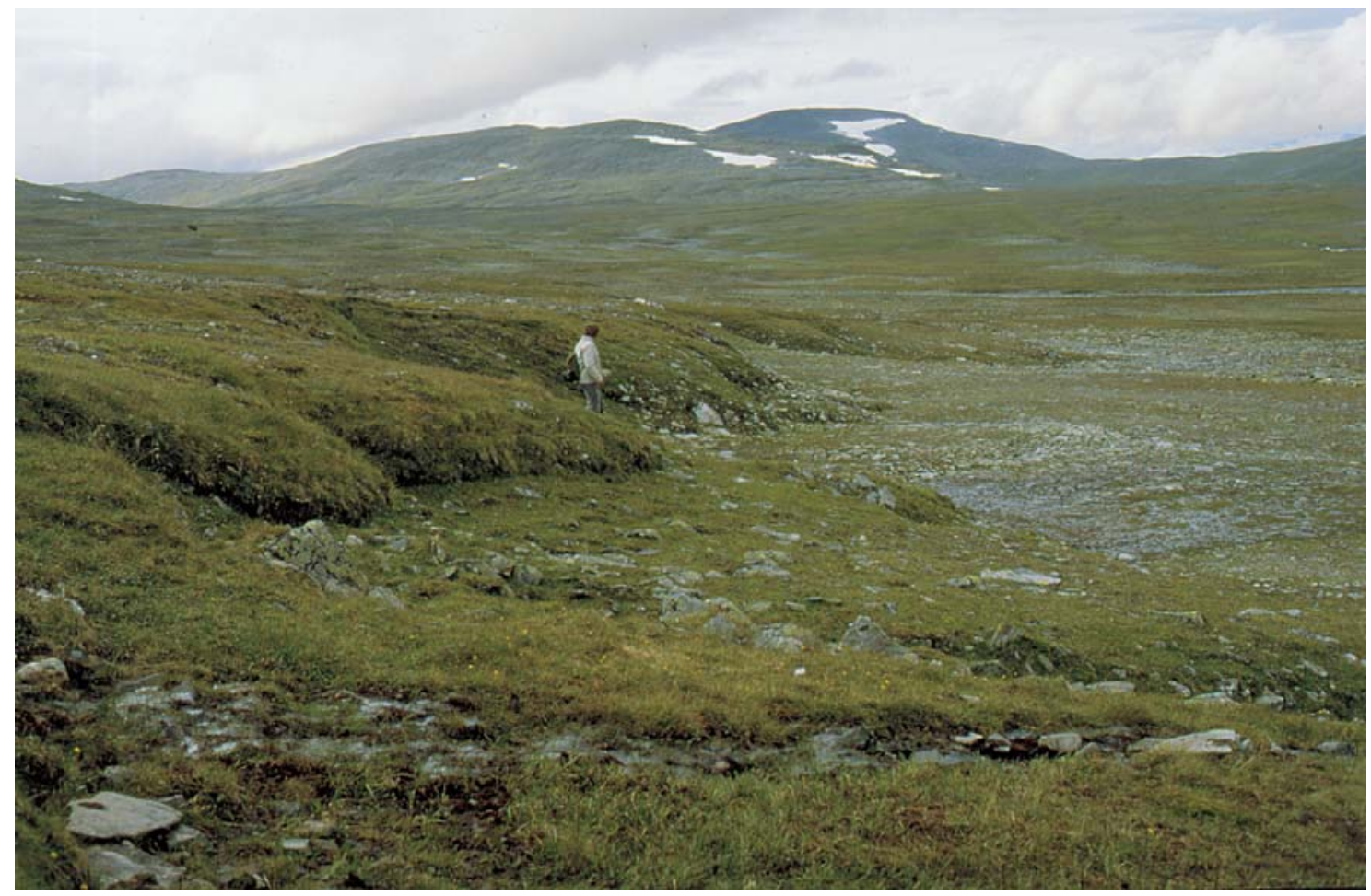

Fig. 3. An example of solifluction terrace on the eastern slope of Ridnitšohkka. One individual terrace can be traced nearly $1 \mathrm{~km}$. In minor scale the terraces have morphology of numerous lobes.

of between $970-850 \mathrm{~m}$, there are some 30 subparallel till terraces of which the largest are $2-4 \mathrm{~m}$ high and up to a kilometre in length. The uppermost parts of these till terraces are free of plant cover and very rocky, whereas lower down they are covered by vegetation and have a typical lobate morphology (Fig. 3). The disposition of boulders on the upper slopes and the presence of patches of disagregated till material on top of some boulders indicate that solifluction processes are actively operating in the area.

\section{STUDY METHODS}

The thickness and internal structures of the Ridnitšohkka snowfield were elucidated with the aid of ground penetrating radar, using a frequency of $500 \mathrm{MHz}$. The survey was carried out with a Sir-3 equipment along three separate down-slope profiles. Targets for drilling were selected on the basis of the survey results, in areas where the snow cover was deepest and where the basal part of the profiles showed prominent reflectors (Fig. 4).

Reconnaissance drilling was carried out to accurately ascertain the thickness of the snowfield, using a $50 \mathrm{~mm}$ diameter drill, while a continuous section of core material was obtained with a CRREL ice-coring drill. The drilling site is located in the south-eastern part of the snowfield, about midway along the slope, at an elevation of $1219 \mathrm{~m}$ above sea level (Fig. 2). The snow cores were sealed in airtight plastic bags prior to storage in frozen carbon dioxide in insulated boxes.

Samples were sawn to size suitable for density measurements and texture analysis at the Technical Research Centre of Finland. The ice samples were photographed and the continuity of layering and the distribution and shapes of air bubbles in the sawn slices were examined.

A $2 \times 2 \mathrm{~m}$ test pit $3.5 \mathrm{~m}$ deep was dug next to the drill site in order to document the stratigraph- 
$500 \mathrm{MHz} / 100 \mathrm{~ns}$

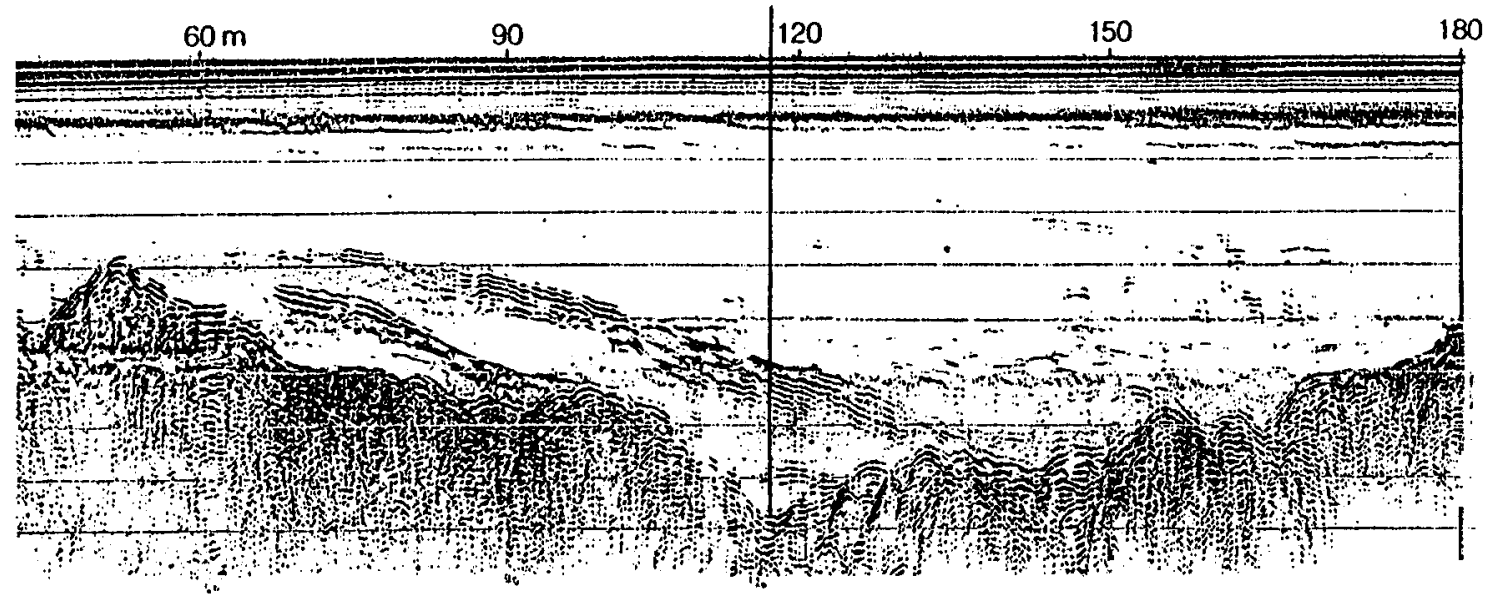

Fig. 4. Ground penetrating radar profile of the Ridnitšohkka snowfield. The sounding profile is a down-slope profile in which the upper slope is located at the left-hand side. Note the strong reflections dipping to the lower flanks of the snowfield, which according to drilling results are caused by ice lenses. The surface of the snowfield is drawn as horizontal in the profile, but it actually dips to the right at about 25 degrees. At the core site the thickness of the snowfield was $6.2 \mathrm{~m}$.

ical and density variations with depth. The in situ density measurements were performed with a Korhonen-Melander ice/snow balance only on the upper part of snow due to too hard snow in the lower part of the test pit. Organic material found at a depth of $4.05 \mathrm{~m}$ within the core was dated at the Uppsala University using the AMS radiocarbon method.

Possible variations in the extent of the snowfield over time were assessed by comparing a series of aerial photographs taken in 1960, 1969, 1975, 1979, 1985 and 1991, and also by measuring the diameter of lichen in the proximity to the snowfield. The distribution of lichen growth of different size was determined visually at first, and several zones more or less concentric with respect to the margin of the snowfield were identified. At each site the diameters of 100 lichens growing on adjacent boulders were measured. Although no attempt was made to identify specific taxa, the lichen measured evidently belonged to the species Rhizocarpon geographicum and $R$. alpicola.

The till cover at the summit plateau of Ridnitšohkka was drilled in two places using a portable Cobra percussion drill. The drilling sites were selected in the centre of a patterned ground area in the middle of nonsorted polygons free of vegetation cover. The proportion of stones and moisture content, and the possible presence of frozen ground were determined from penetration rate and resistance during drilling. Excavations were also carried out to obtain further information about the physical properties of the till.

\section{RESULTS}

The earliest written records of a permanent snowfield near the summit of Ridnitšohkka date from the latter part of the $19^{\text {th }}$ century (Stjernvall 1892). A continuous snowfield is present at elevations of between $1270-1180 \mathrm{~m}$ on the northern and eastern flanks of the fell, with a maximum width of $600 \mathrm{~m}$ and a length of nearly $5 \mathrm{~km}$.

The results of the ground penetrating radar survey revealed that the surface of the snowfield does not conform to that of the underlying topography. The radar profile in Fig. 4 shows a distinct series of reflections that dip down-slope towards the edge of the snowfield. The results of drilling showed that the snowfield is $6.2 \mathrm{~m}$ thick at the point indicated on the profile. 
The study pit revealed the presence of distinct lenses and layers of ice from 0.2 to $3.0 \mathrm{~cm}$ thick. These were generally discontinuous and conformable with the surface of the snowfield. More continuous layers that could be traced from one wall to another were found towards the base of the excavation. In some cases a narrow vertical wall of ice was present, joining layers of ice at different levels and resulting in a reticulate network of ice lenses surrounded by less crystalline snow. The stacked ice lenses were typically about $5-15 \mathrm{~cm}$ apart, such that up to $35-45$ lenses were present in the excavation walls.

Stratigraphical information from the basal part of the snowfield was obtained by analysis of drill core, although the dip and strike of the ice lenses remained unknown because it was not possible to take oriented samples. The core had a distinctly banded structure, formed by numerous laminae of ice 2-20 mm thick (Fig. 5). The interface between the ice lenses and snow was sharp. Ice was clearer than snow and a few air bubbles were observed within the ice lenses. The diameter of the single air bubbles was 1-2 $\mathrm{mm}$. The shape of single air bubbles was rounded, but normally air inclusions were polymorphic, because the air inclusions were composed of several air bubbles. The laminae form an angle of about 25 degrees with the long axis of the core and because the ice layers exposed in the adjacent excavation dip parallel to the surface, it is probable that the layering in the deeper material sampled by drilling is also broadly concordant. At the depth of 3,80-3,95 m some light vertical ice lenses were observed. These layers are results of water flow through the snowfield. The bottom part of the snowfield consists of tightly compressed but wet recrystallized snow/ice, underlain by frost-shattered angular clasts of local bedrock.

Density measurements carried out on the drill core and in the study pits revealed a range of values, from 540 to $670 \mathrm{~kg}$ per cubic metre (Fig. 6), which according to Paterson (1994) falls within the typical range of densities for firn. Density measurements were not performed from the separate ice lenses. Density appears to increase downwards, which is in agreement with the concomi-

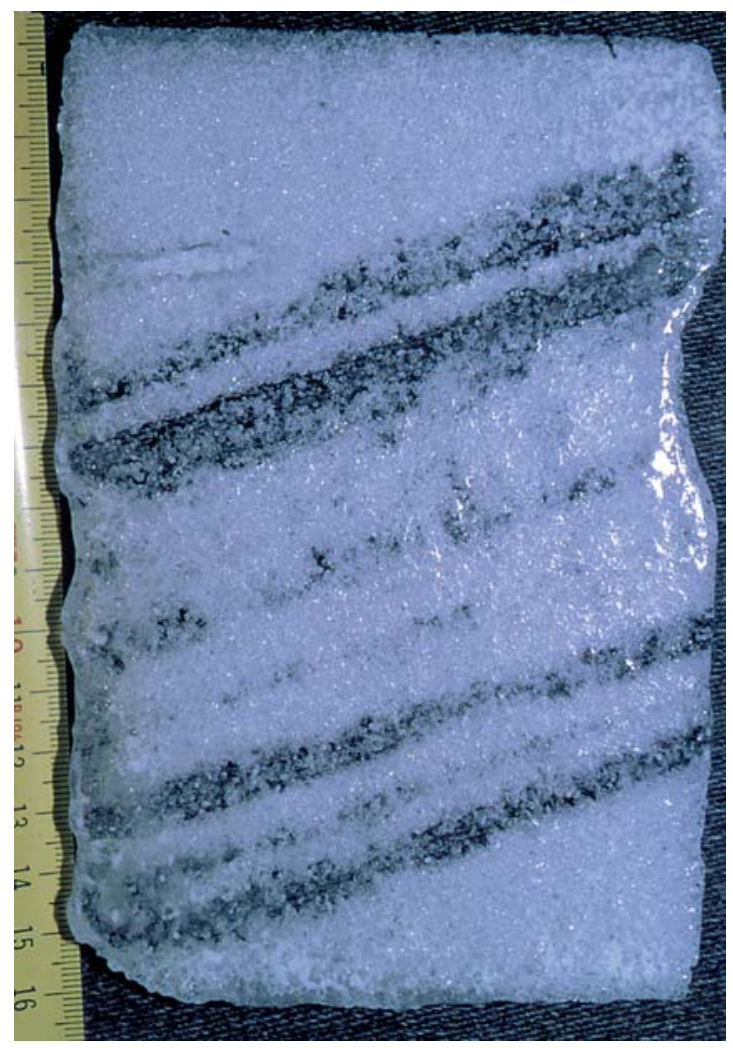

Fig. 5. Ice layers at the depth of 3.20-3.35 $\mathrm{m}$ in a core from the Ridnitšohkka snowfield. Note the ice lamination containing air bubbles.

tant increase in the abundance of icy layers and laminae with depth.

The remains of grass and leaves found at a depth of $4.05 \mathrm{~m}$ in the drill core were dated as being 35 years old. The amount of radioactive carbon in sample Ua-2886 was so high that it must post-date the earliest atmospheric nuclear tests, since the value obtained, $\mathrm{A}=109.7 \pm 1.1 \mathrm{pM}$, corresponds to the mean atmospheric radioactivity in the years 1957-1958. This result receives independent confirmation in that a small piece of rounded styrofoam ("styrox") was also found at the same level as the plant remains, and styrofoam was not widely used in Finland prior to 1952.

During the summers of 1991 and 1992 the surface of the snowfield was exceptionally clean, whereas in 1993 the surface was covered by finegrained inorganic and organic debris, either wind 


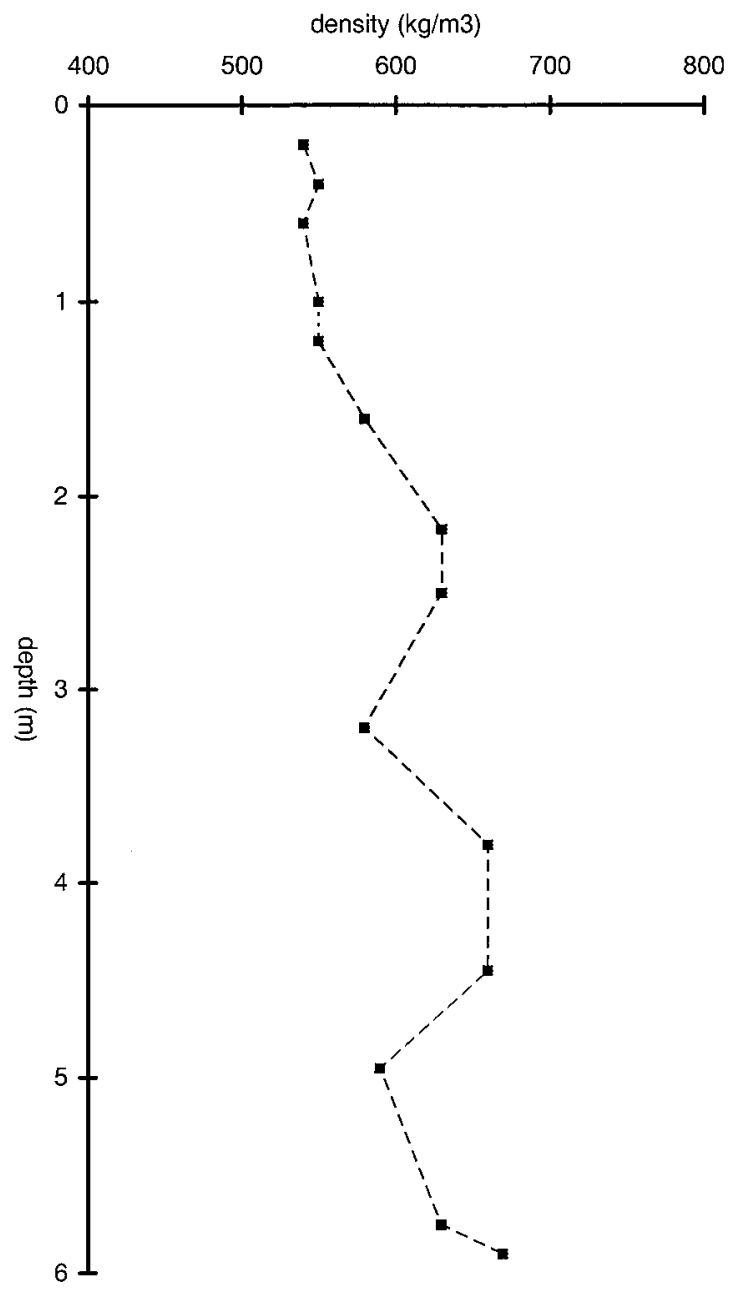

Fig. 6. Density of the drilling and study pit samples from the Ridnitšohkka snowfield. All the densities measured fall in the range of firn.

blown or as accumulations after snow melting and consolidation. However, the study pit showed no readily discernible evidence for intervals containing dust or fine-grained organic matter that might correspond to former snow surfaces. The remains of leaves and grass encountered at a depth of $4.05 \mathrm{~m}$ in the drilling profile evidently represent an isolated example of exotic wind-blown material.

The comparison of aerial photographs taken in late summer 1960, 1969, 1975, 1979, 1985 and 1990 showed no distinct variations in the extent of the snowfield.
The boulder field immediately below the Ridnitšohkka snowfield is characterized by a $50-70 \mathrm{~m}$ wide zone of greyish boulders with only sparse and small growths of lichen, whereas below this zone, lichen tends to be larger and merge together, giving an overall greenish appearance to the rocks. Lichen diameters were measured within the zone of greyish boulders at distances of $5 \mathrm{~m}, 10 \mathrm{~m}$ and $50 \mathrm{~m}$ from the margin of the snowfield but the results failed to show any significant differences in the maximum lichen size at each of the three sites; the largest were about $40 \mathrm{~mm}$ in diameter, while the median size range was 20$25 \mathrm{~mm}$ (Fig. 7).

A study pit was excavated by shovel to a depth of $0.9 \mathrm{~m}$ in the till cover of the Ridnitšohkka summit plateau. The sequence comprised massive sandy till with scattered large clasts and showed no evidence of frozen ground.

Drilling was carried out at two sites on the summit plateau on 29-30 July 1993. The two sites were situated in patterned ground and spaced about twenty metres apart. The individual drilling sites were situated in the centres of nonsorted polygons that were devoid of vegetation cover. In both cases the drill penetrated to a depth of $0.5 \mathrm{~m}$ with minimal effort, the till at this level being saturated with water and leaving the drill rods extremely wet and dirt-covered. Below this depth penetration rate was slower and the material remaining in the flow-through bit was dry. Penetration rate slowed even further at 1.9 and $2.0 \mathrm{~m}$, respectively, in both holes and ceased altogether at 1.97 and $2.0 \mathrm{~m}$. In both cases the drill bits contained $7-10 \mathrm{~cm}$ pieces of frozen till with numerous subparallel, gently dipping laminae of ice 1$2 \mathrm{~mm}$ thick.

\section{CONCLUDING REMARKS}

The ground penetrating radar results showed that the Ridnitšohkka snowfield is situated in a bedrock depression. The age determinations from organic material obtained from a depth of $4.05 \mathrm{~m}$ in the snowfield indicate that the snow is rather young, being at most only a few tens of years old. 
Fig. 7. Typical lichens at the bare rock zone around the Ridnitšohkka snowfield.

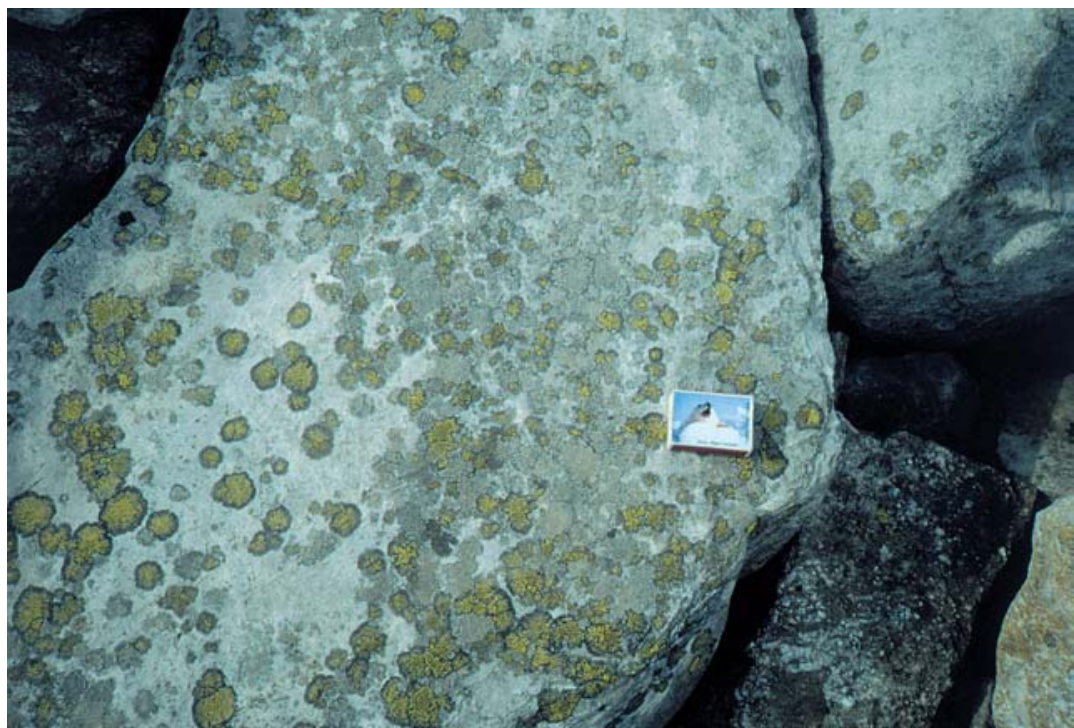

Reliable historical records show that the snowfield was in existence in the latter part of $19^{\text {th }}$ century (Stjernvall 1892), suggesting that it is stable under the current climatic regime.

Investigations of lichen growth and distribution at Kebnekaisa in nearby Swedish Lapland suggest that diameters of $40 \mathrm{~mm}$ correspond to ages of 130-140 years (Karlén 1975). There are numerous uncertainties in comparing the Kebnekaise results with data from Ridnitšohkka, such as variable growth rates of lichen on different substrates and the effects of microclimatic variations in temperature and precipitation. In general however, climatic conditions at Ridnitšohkka resemble those at Kebnekaisa and the results of lichen studies can be taken to infer that the Ridnitšohkka snowfield was more extensive in the middle part the $19^{\text {th }}$ century than at present. This period corresponds to a documented event of the Little Ice Age, during which time a number of glaciers in Norway and Sweden advanced significantly (Karlén 1982, 1984).

The presence of a perennial snowfield, solifluction terraces and actively forming patterned ground devoid of vegetation cover all indicate the severity of the current climatic regime at the summit of Ridnitšohkka. The discovery of frozen till near the summit in late summer also shows that frozen ground can locally survive from one season to the next, while the extent of the permanent snowfield and vegetation-free patterned ground suggest that permafrost might have existed over wider areas. The summit itself is commonly almost free of snow during winter (P. Leinonen, oral communication), due to its exposed aspect, which allows freezing to proceed to a greater depth than in areas beneath a thick snow cover.

The frozen till found at the end of the summer season at an elevation of 1290 m on Ridnitšohkka is evidently the first record of at least semi-permanent frozen ground at such altitudes in the fell country of northern Finland, the summits of fells being in general either bare rock or frost-shattered boulder fields. In the present case, however, the proximity of frozen ground and the largest permanent snowfield in Finland, together with associated solifluction lobes and actively forming patterned ground, suggest that our results may also be a candidate for being the first recorded occurrence of permafrost in till in Finnish Lapland.

ACKNOWLEDGEMENTS. We would like to express our appreciation to all those people and organisations who assisted us, in particular the Topographic Service and the Finnish Air Force for helicopter air-lifts, and Tele and the Finnish Bor- 
der Guard for making cabin accommodation available. We also thank the staff of the Kilpisjärvi Biological Research Station for allowing frozen storage of the sample material and the Technical Research Centre of Finland for providing laboratory facilities for sample investigation. The Finnish Meteorological Institute also kindly allowed us to use a snow density meter.

\section{REFERENCES}

Finnish Meteorological Institute 1991. Climatological statistics in Finland 1961-1990. Meteorological yearbook of Finland 90, Part 1:1990. 125 p.

Helminen, V.A. 1987. Temperature conditions. In: Alalammi, P. (ed.) Atlas of Finland, Folio 131, Climate. National Board of Survey and Geographical Society of Finland, Maanmittaushallitus, Helsinki.

Hirvas, H. 1968. Haltin alueen kvartäärisestä kehityksestä. Unpublished M.Sc. thesis, University of Helsinki, Department of Geology. 67 p. (in Finnish)

Hirvas, H. 1990. Pleistocene stratigraphy of Lapland. Geological Survey of Finland, Bulletin 354. 123 p.

Karlén, W. 1975. Licenometrisk datering i norra Skandinavien - metodens tillförlitlighet och regionala tillämpning. Stockholms Universitet, Naturgeografiska Institutionen, Raport 22. 67 p.

Karlén, W. 1982. Holocene glacier fluctuations in Scandinavia. Striae 18, 26-34.

Karlén, W. 1984. Dendrochronology, mass balance and glacial front fluctuations in northern Sweden. In: Mörner, N.-A. \& Karlén, W. (eds.) Climatic Changes on a Yearly to Millennial Basis. Dordrecht: D. Reidel Publishing Company, 263-271.

King, L. \& Seppälä, M. 1987. Permafrost thickness and distribution in Finnish Lapland - results of geoeletrical soundings. Polarforschung 57, 127-147.
Kujansuu, R. 1967. On the deglaciation of western Finnish Lapland. Bulletin de la Commission Géologique de Finlande 232. 98 p.

Kujansuu, R. 1992. The deglaciation of Finnish Lapland. In: Kauranne, K. (ed.) Glacial stratigraphy, engineering geology and earth construction. Geological Survey of Finland, Special Paper 15, 21-31.

Laaksonen, K. 1976. The dependence of mean air temperatures upon latitude and altitude in Fennoscandia (19211950). Annales Academiae Scientiarum Fennicae A. III 119. $19 \mathrm{p}$.

Lehtovaara, J. 1995. Kilpisjärven ja Haltin kartta-alueiden kallioperä. Summary: Pre-Quaternary rocks of the Kilpisjärvi and Halti map-sheet areas. Geological map of Finland $1: 100$ 000, Explanation to the maps of preQuaternary rocks, Sheets 1823 and 1842, Geological Survey of Finland. 64 p.

Østrem, G. 1964. Ice-cored moraines in Scandinavia. Geografiska Annaler XLVI, 282-337.

Paterson, W.S.B. 1994. The Physics of Glaciers. Third edition. Oxford: Elsevier. 480 p.

Péwé, T.I. 1979. Permafrost and its affects on human activities in Arctic and Subarctic regions. Geo Journal 3, 333-344.

Putkonen, J. 1990. Ikiroudan aktiivikerros. Summary: Permafrost active layer. Geologi 42, 161-166.

Saarelainen, S. 1990. Routavaurioiden korjausrakenteet valtatiellä 21 Peerassa. Mitoitus, koerakentaminen ja seuranta v. 1986-1988. Summary: Repair structures of frost damages on main road 21 at Peera, Northern Finland. Design, construction and monitoring during 19861988. Technical Research Centre of Finland, Research Notes 1102. 62 p.

Simonen, A. 1980. The Precambrian in Finland. Geological Survey of Finland, Bulletin 304. 58 p.

Stjernvall, H.J. 1892. Bidrag till Finska Lappmarkens geognosi II. Försök till framställning af de geologiska förhållandena mellan Könkämäeno och norska gränsen. Meddelanden från industristyrelsen 17, Helsingfors, 95146 . 